Sprawozdania / Reports

Maciej Topolewski

ORCID: 0000-0003-4830-1390 maciej.topolewski@awf.edu.pl

Akademia Wychowania Fizycznego Józefa Piłsudskiego w Warszawie

Wydział Wychowania Fizycznego

\title{
VI Ogólnopolska Konferencja Naukowa z cyklu „Bezpieczeństwo informacyjne" na temat: „Współczesne szanse, wyzwania i zagrożenia dla informacyjnego wymiaru bezpieczeństwa państwa", Siedlce, 27 stycznia 2021 r.
}

\section{DOI: 10.34739/doc.2021.18.25}

Konferencja „Współczesne szanse, wyzwania i zagrożenia dla informacyjnego wymiaru bezpieczeństwa" była szóstym spotkaniem naukowym, zorganizowanym przez Instytut Nauk o Bezpieczeństwie Uniwersytetu Przyrodniczo-Humanistycznego w Siedlcach w ramach corocznych konferencji $z$ cyklu „Bezpieczeństwo informacyjne". Tegoroczna edycja ze względu na sytuację epidemiczna odbyła się z wykorzystaniem łączy internetowych. Współorganizatorami konferencji byli: Instytut Nauk Społecznych Akademii Katolickiej w Warszawie, Wydział Nauk Społecznych Uczelni SpołecznoMedycznej w Warszawie, Instytut Analizy Ryzyka, Instytut Nauk o Bezpieczeństwie Uniwersytetu Pedagogicznego im. Komisji Edukacji Narodowej w Krakowie, Instytut Nauk o Bezpieczeństwie Akademii Kaliskiej im. Prezydenta S. Wojciechowskiego, Kolegium Zarzązania i Bezpieczeństwa Szkoły Wyższej im. Pawła Włodkowica w Płocku, a także Europejskie Stowarzyszenie Nauk o Bezpieczeństwie (European Association for Security).

Tematyka zaprezentowanych rozważań dotyczyła zagadnień z zakresu prawnych i instytucjonalno-organizacyjnych uwarunko- 
wań ochrony informacji, przestępczości w sferze informacyjnej, zagrożeń oraz wyzwań dla swobody dostępu i wymiany informacji, a także obaw zwiazanych ze stosowaniem nowych technologii $\mathrm{w}$ infosferze. Podobnie jak w latach ubiegłych prelegenci poruszali wątki, dotyczące bezpieczeństwa informacyjnego $\mathrm{w}$ różnych dziedzinach życia publicznego, wskazując na szanse i zagrożenia, wynikajace ze zmian technologiczno cywilizacyjnych oraz obecnie obwiązujących uwarunkowań prawnych, organizacyjnych, społeczno-politycznych i kulturowych. Podczas otwarcia konferencji znaczenie problematyki bezpieczeństwa informacyjnego we współczesnym, nasyconym informacją świecie podkreślali: przewodniczący komitetu naukowego konferencji dyrektor Instytutu Nauk o Bezpieczeństwie Wydziału Nauk Społecznych UPH dr hab. prof. uczelni Stanisław Topolewski oraz przewodniczacy komitetu organizacyjnego dr hab. prof. uczelni Włodzimierz Fehler, wskazując jednocześnie na coraz bardziej istotna rolę badań i dyskusji naukowych w tej dziedzinie.

Wygłoszone referaty zawierały szerokie spektrum odniesień do różnorodnych zagadnień ze sfery bezpieczeństwa informacyjnego. Watki natury społeczno-politycznej zostały poruszone w wystapieniach: „Techniki dezinformacyjne stosowane przez Rosję wobec Państw Europy Środkowo Wschodniej" (prof. dr hab. Olga Wasiuta, Uniwersytet Pedagogiczny im. Komisji Edukacji Narodowej w Krakowie), „Wyzwania informacyjne w państwie z gospodarka oparta na wiedzy" (dr hab. prof. KUL Kinga Machowicz, Katolicki Uniwersytet Lubelski Jana Pawła II), „Międzynarodowe kompleksowe inicjatywy wywiadowcze i rozpoznawcze jako szansa i zagrożenie dla bezpieczeństwa współczesnych państw" (dr Maria Hapunik, Komenda Wojewódzka Policji w Białymstoku), „Dezinformacja w dyplomacji” (dr hab. prof. uczelni Mariusz Kubiak, Uniwersytet Przyrodniczo-Humanistyczny w Siedlcach), „Nadzór i kontrola Internetu jako instrument polityki bezpieczeństwa informacyjnego współczesnych państw" (dr Daria Krzewniak, Uniwersytet PrzyrodniczoHumanistyczny w Siedlcach), „Zagrożenia dla bezpieczeństwa państwa w kontekście funkcjonowania systemu dostępu do informacji publicznej" (dr Piotr Swoboda, Uniwersytet Pedagogiczny im. Komisji Edukacji Narodowej w Krakowie), „Ochrona informacji niejawnych jako element polityki bezpieczeństwa informacyjnego Rzecz- 
pospolitej Polskiej po 2010 roku” (mgr Urszula Adamczyk, mgr Łukasz Adamczyk, Polska Grupa Zbrojeniowa), „Unia Europejska wobec zapobiegania i zwalczania cyberprzestępczości - wybrane aspekty" (mgr Łukasz Olszewski, Uniwersytet PrzyrodniczoHumanistyczny w Siedlcach) oraz „Praktyczne założenia "polityki informacjonizmu" w oparciu o teorię społeczna Manuela Castellasa" (ks. dr Jarosław Charchuła SJ, Akademia Ignatianum w Krakowie).

W ramach refleksji w obszarze uwarunkowań instytucjonalno-organizacyjnych i prawnych zaprezentowane zostały wystapienia: „Konstytucyjne podstawy ograniczenia dostępu do informacji w III RP” (dr Robert Zapart, Uniwersytet Rzeszowski), „Informacja jako czynnik warunkujący bezpieczeństwo współczesnych organizacji” (dr Jowita Sobczak, Warszawska Szkoła Zarządzania - Szkoła Wyższa), „Wyzwania i zagrożenia dla bezpieczeństwa informacyjnego w świetle uprawnień służb policyjnych III RP” (mgr Andrzej Dziewulski, Uniwersytet Przyrodniczo-Humanistyczny w Siedlcach), „Przestępczość informacyjna” (dr hab. prof. uczelni Włodzimierz Fehler, Uniwersytet Przyrodniczo-Humanistyczny w Siedlcach), „Współczesne i perspektywiczne formy zagrożeń dla bezpieczeństwa informacji niejawnych" (dr hab. prof. uczelni Stanisław Topolewski, Uniwersytet Przyrodniczo-Humanistyczny w Siedlcach), „Informacyjne aspekty stanów nadzwyczajnych w III RP” (dr hab. prof. uczelni Ireneusz Dziubek, dr. Bogumiła Pawlaczyk, Akademia Kaliska im. Prezydenta S. Wojciechowskiego) oraz „Policyjne systemy informacyjne w zarządzaniu bezpieczeństwem wewnętrznym III RP” (dr Łukasz Świerczewski, Uniwersytet Przyrodniczo-Humanistyczny w Siedlcach).

Konteksty historyczne oraz teoretyczne refleksje dotyczące istoty bezpieczeństwa informacyjnego przedstawione zostały w referatach: „Bezpieczeństwo informacyjne, geneza zagadnienia” (ks. dr inż. Robert Wawer SJ, Akademia Katolicka w Warszawie), „Językowe aspekty bezpieczeństwa informacyjnego" (dr Renata Tarasiuk, Uniwersytet Przyrodniczo-Humanistyczny w Siedlcach), „Ujawnienie informacji niejawnych. Studia przypadku” (dr hab. prof. uczelni Sławomir Zalewski, Szkoła Wyższa im. Pawła Włodkowica w Płocku).

Kwestie szeregu wyzwań oraz zagrożeń dla informacyjnego wymiaru bezpieczeństwa ujęte zostały w referatach: „Ekologia informacji a bezpieczeństwo człowieka” (dr Joanna Ważniewska, 
Uniwersytet Przyrodniczo-Humanistyczny w Siedlcach), „Wyzwania i zagrożenia dezinformacyjne w kontekście rozwoju Sztucznej Inteligencji" (mgr Piotr Baczek, Akademia im. Aleksandra Gieysztora w Pułtusku Filia Akademii Finansów i Bizensu Vistula), „Bezpieczeństwo i wiarygodność informacji medycznej w czasach pandemii" (dr Blanka Ulażzka, Uczelnia Społeczno-Medyczna w Warszawie), „Infrastruktura informacyjna w obliczu wyzwań i zagrożeń XXI wieku” (dr hab. prof. uczelni Tomasz Skrzyński, Uniwersytet Pedagogiczny im. Komisji Edukacji Narodowej w Krakowie), „Kształtowanie bezpieczeństwa informacyjnego w rodzinie” (dr hab. prof. uczelni Agnieszka Filipek, Uniwersytet Przyrodniczo-Humanistyczny w Siedlcach), „Szanse i zagrożenia w przekazie informacji w zdalnym nauczaniu szkolnym w czasie pandemii” (mgr Maciej Topolewski, Akademia Wychowania Fizycznego w Warszawie), „Wyzwania i zagrożenia informacyjne w sferze planowania przestrzennego" (mgr inż. Kinga Augustyniak, Uczelnia Społeczno-Medyczna w Warszawie) oraz „Media społecznościowe jako informacyjne narzędzie działania grup terrorystycznych” (mgr inż. Waldemar Gołuchowski, Uniwersytet Przyrodniczo-Humanistyczny w Siedlcach).

$\mathrm{W}$ ramach podsumowania organizatorzy konferencji ocenili wydarzenie jako obfitujace $\mathrm{w}$ ciekawe $\mathrm{i}$ oryginalne wystapienia. Zaznaczyli także wage poruszanej problematyki, uwypuklając konieczność kontynuowania badań w tej tak istotnej dla bezpieczeństwa jednostek, grup społecznych, państw oraz społeczności międzynarodowej sferze, jaka jest bezpieczeństwo informacyjne. Również w opiniach kilkudziesięciu czynnych uczestników z 10 ośrodków naukowych, wyrażanych podczas wystąpień i towarzyszacych im dyskusji, jednoznacznie formułowany był postulat kontynuowania konferencji w ramach kolejnych edycji. Warto zaznaczyć, że użycie łączy internetowych i programu Microsoft Teams pozwoliło na transmisję „na żywo" dla zainteresowanych odbiorców zewnętrznych, w tym studentów uczelni zaangażowanych w konferencję. 